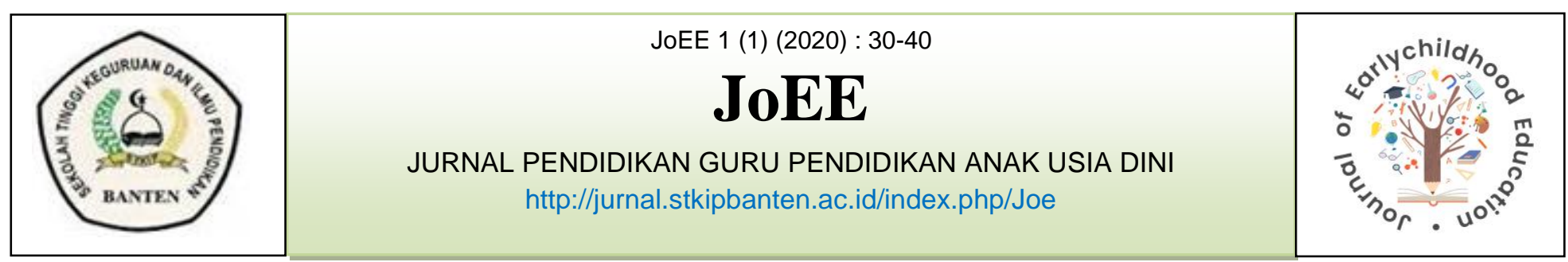

\title{
MENINGKATKAN KEMAMPUAN MOTORIK KASAR ANAK USIA DINI MELALUI GERAK DAN LAGU “BERNYANYI DENGAN RIANG”
}

\author{
Alvan Hazhari \\ hazharialvan@gmail.com \\ Pendidikan Guru Pendidikan Anak Usia Dini \\ Sekolah Tinggi Keguruan dan Ilmu Pendidikan Banten
}

\begin{abstract}
Abstrak
Pendidikan diperlukan bagai anak usia dini untuk mengembangkan semua aspek perkembangan anak melalui desain pembelajaran yang menyenangkan bagi anak. Pendidikan anak usia dini merupakan pondasi dasar pendidikan, yang memiliki peranan penting dalam mengembangkan kemampuan dasar dan meningkatkan potensi kecerdasan anak yang akan mempengaruhi pendidikan di tingkat selanjutnya. Tujuan penelitian ini adalah untuk mengetahui peningkatkan kemampuan motorik kasar anak usia dini melalui gerak dan lagu "Bernyanyi dengan Riang". Peneltian ini adalah penelitian kepustakaan ( Library Research), Pengumpulan data peneliti menggunakan paper dan journal ilmiah, skripsi dan buku. Teknik analisis data dengan menggunakan reduksi data, display data, dan menarik kesimpulan. Hasil penelitian yang telah dilakukan oleh peneliti baik jurnal maupun skripsi menunjukan adanya peningkatan kemampuan motorik kasar dengan menggunakan gerak dan lagu, artinya terdapat peningkatan motorik kasar pada anak usia dini dengan menggunakan gerak dan lagu "bernyanyi dengan riang". Karena dengan gerak dan lagu peserta didik merasa senang dan bahagia serta dapat mengingat pesan moral, pesan agama, dan gerakan-gerakan yang diajarkan.
\end{abstract}

Kata Kunci : Gerak dan lagu, Kemampuan Motorik Kasar.

\section{Pendahuluan}

Masa usia dini merupakan masa peletak dasar atau pondasi awal bagi pertumbuhan dan perkembangan anak. Apa yang diterima anak pada masa usia dini, apakah itu makanan, minuman, serta stimulasi dari lingkungan memberikan kontribusi yang sangat besar pada pertumbuhan dan perkembangan anak pada masa itu dan berpengaruh besar pada pertumbuhan dan perkembangan selanjutnya.

Lima tahun pertama kehidupan anak merupakan peletak dasar bagi perkembangan selanjutnya. Anak yang mengalami kebahagiaan pada masa ini, akan dapat melaksanakan tugas-tugas perkembangan selanjutnya. Namun 
apabila anak mengalami tekanan pada usia ini, maka anak akan mengalami permasalahan pada perkembangan yang selanjutnya.

Pada masa ini anak-anak diperkenalkan berbagai pengetahuan, sikap atau perilaku, dan ketrampilan agar anak dapat melanjutkan kegiatan belajar yang sesungguhnya pada jenjang pendidikan yang selanjutnya. Diharpkan dengan pengetahuan, sikap, dan keterampilan dapat mengantarkan anak menjadi anak yang cerdas.

Dunia anak-anak merupakan dunia khas yang diindera dan dipersiapkan oleh anak-anak sesuai dengan kemampuan pikiran, perasaan, imajinasi dan pengalaman mereka. Dibutuhkan kepedulian untuk memahami dunia ini apabila ingin memenuhi kebutuhan anak dan memenuhi perkembangan mereka. Upaya yang perlu dilakukan guna mengembangkan kemampuan serta meningkatkan mutu kehidupan seorang anak salah satunya ialah pendidikan.

Di Indonesia anak usia dini berada pada rentang usia 0-6 tahun. Perkembangan anak usia dini merupakan perkembangan usia emas yang sangat memiliki makna bagi kehidupan mereka, jika usia emas itu dioptimalkan pertumbuhannya melalui pendidikan yang tepat. Dalam UndangUndang Nomor 20 tahun 2003 tentang Sistem Pendidikan Nasional pasal 1 ayat 14 dinyatakan bahwa "Pendidikan anak usia dini adalah suatu upaya pembinaan yang ditujukan kepada anak sejak lahir sampai dengan usia enam tahun yang dilakukan melalui pemberian rangsangan pendidikan untuk membantu pertumbuhan dan perkembangan jasmani dan rohani agar anak memiliki kesiapan dalam memasuki pendidikan lebih lanjut"1.

Pendidikan diperlukan bagai anak usia dini untuk mengembangkan semua aspek perkembangan anak melalui desain pembelajaran yang menyenangkan bagi anak. Pendidikan anak usia dini merupakan pondasi dasar pendidikan, yang memiliki peranan penting dalam mengembangkan kemampuan dasar dan meningkatkan potensi kecerdasan anak yang akan mempengaruhi pendidikan di tingkat selanjutnya.

Kemampuan gerak yang dimiliki oleh seseorang meliputi gerak lokomotor, non lokomotor dan gerak manipulatif. Gerak lokomotor adalah gerak yang membutuhkan perpindahan tempat, misalnya berjalan, berlari, melompat, dan lain-lain. Gerak nonlokomotor adalah suatu gerakan yang tidak menyebabkan pelakunya berpindah tempat, seperti membungkuk, memutar, mengayun, memilin, mengangkat, merentang dan lain-lain. Untuk memadukan gerakan lokomotor dan nonlokomotor ini diperlukan adanya koordinasi antara tangan dan kaki.

\footnotetext{
${ }^{1}$ Suyadi.Ibid,. hal 23.
} 


\section{Metode}

Penelitian Studi literature dilakukan dengan cara mempelajari dan mengkaji buku-buku yang ada hubungannya denvgan masalah yang diteliti untuk memperoleh banhanbahan atau sumber-sumber tentang masalah yang akan diteliti. Teknik ini selain digunakan untuk melengkapi serta memperkuat landasan peneliti sebelum melakukan penelitiaan juga untuk melengkapi hasil penelitian yang peneliti lakukan ${ }^{2}$.

Jenis penelitian ini adalah penelitan kepustakaan (library research), yaitu serangkaian penelitian yang berkenaan dengan metode pengumpulan data pustaka, atau penelitian yang obyek penelitiannya digali melalui beragam informasi kepustakaan (buku, ensiklopedi, jurnal ilmiah, koran, majalah, dan dokumen) ${ }^{3}$. Penelitian kepustakaan atau kajian literatur (literature review, literature research) merupakan penelitian yang mengkaji atau meninjau secara kritis pengetahuan, gagasan, atau temuan yang terdapat didalam tubuh literatur berorientasi akademik (academicoriented literature), serta merumuskan kontribusi teoritis dan metodologisnya untuk topik tertentu. Cooper dan Taylor dalam fokus penelitian kepustakaan adalah menemukanberbagai teori, hukum, dalil, prinsip, atau gagasan yang digunakan untuk menganalisis dan memecahkan pertanyaan penelitian yang dirumuskan.

\footnotetext{
${ }^{2}$ Diantama.Suarifqi, Metode Penelitian

Pendidikan. Bandung:Pustaka Rahmat, 2018.

Hal 34

${ }^{3}$ Nana Syaodih. 2010. Metode Penelitian

Pendidikan. PT. Remaja Rosdakarya : Bandung. h.52
}

Analisis data merupakan upaya mencari dan menata secara sistematis data yang telah terkumpul untuk meningkatkan pemahaman penelitian tentang kasus yang diteliti dan mengkajinya sebagai temuan bagi orang lain ${ }^{4}$.Analisis data yang digunakan dalam penelitian ini adalah analisis anotasi bibliografi (annotated bibliography). Anotasi berarti suatu kesimpulan sederhana dari suatu artikel, buku, jurnal, atau beberapa sumber tulisan yang lain, sedangkan bibliografi diartikan sebagai suatu daftar sumber dari suatu topik ${ }^{5}$.

\section{Reduksi Data}

Dalam kaitan ini peneliti mereduksi data yang telah didapat dari hasil observasi dan wawancara dan dirangkum satu per satu agar memudahkan peneliti dalam memfokuskan data. Data yang tidak terkait dengan permasalahahan tidak disajikan dalam bentuk laporan.

\section{Display Data}

Setelah data direduksi maka langkah selanjutnya adalah menyajikan data (Display Data). Data yang berupa tulisan tersebut disusun kembali secara baik dan akurat untuk dapat memperoleh kesimpulan yang valid sehingga lebih memudahkan peneliti

\footnotetext{
${ }^{4}$ Noeng Mohadjir dalam Yuni Irawati. 2013. Metode Pendidikan Karakter Islami Terhadap Anak Menurut Abdullah Nasih Ulwan dalam Buku Pendidikan Anak dalam Islam dan Relevansinya dengan Tujuan Pendidikan Nasional. Skripsi tidak diterbitkan. UIN Sunan Kalijaga. h.28.

${ }^{5}$ The UCSC University Library. Write a Literature Review (http://guides.library.ucsc.edu/write-a-literaturereview diakses tanggal 15 Mei 2020).
} 
dalam memahami. Penyajian data dalam penelitian kualitatif berbentuk uraian yang singkat dan jelas.

\section{Menarik Kesimpulan}

Penarikan kesimpulan merupakan bagian dari aktivitas data. Aktivitas ini dimaksudkan untuk memberikan makna terhadap hasil analisis, menjelaskan pola urutan dan mencari hubungan diantara dimensi-dimensi yang diuraikan. Disamping itu, kendati data telah disajikan bukan berarti proses analisis data sudah final.

Teknik pengujian keabsahan data ini menggunakan triangulasi data. Menurut Sugiyono dalam Suarifqi mengungkapkan bahwa triangulasi data dalam pengujian kredibilitas ini di artikan sebagai pengecekan data dari berbagai sumber dengan berbagai cara, dan berbagai waktu. Dalam penelitian ini triangulasi dilakukan terhadap informasi yang diberikan dari berbagai jurnal

\section{Hasil dan Pembahasan}

\section{Hasil Penelitian}

Hasil presentase penggunan metode Gerak dan lagu untuk meningkatkan kemampuan motorik kasar anak usia dini menunjukan bahwa data Penulis 1 hasil presentase dari $35 \%$ menjadi $85 \%$ sehingga peningkatan yang diperoleh sebanyak 50\%

Data Penulis 2 hasil presentse dari $60,16 \%$ menjadi $83 \%$ sehingga peningkatan yang diperoleh sebanyak $22,84 \%$. Data Penulis 3 hasil presentase $50 \%$ menjadi $94 \%$ sehingga peningkatan yang diperoleh sebanyak $44 \%$. Data Penulis 4 hasil presentase $66,60 \%$ menjadi $85,90 \%$ sehingga peningkatan yang diperoleh sebanyak $19,3 \%$.
Data Penulis 5 hasil presentase $53,7 \%$ menjadi $97,9 \%$ sehingga peningkatan yang diperoleh sebanyak $44,2 \%$. Data Penulis 6 hasil presentase $53 \%$ menjadi $82 \%$ sehingga peningkatan yang diperoleh sebanyak $29 \%$. Data Penulis 7 hasil presentase $61,52 \%$ menjadi $84,6 \%$ sehingga peningkatan yang diperoleh sebanyak $23,08 \%$.

Dengan nilai rata-rata keseluruhan dari literatur yang dijadikan bahan penelitian dengan skor siklus I 54,28\% meningkat menjadi $87,48 \%$ dengan selisih rata-rata menjadi $33,20 \%$. Jadi, dari hasil penelitian literatur skripsi dan jurnal dengan pendekatan pembelajaran penggunaan metode gerak dan lagu untuk meningkatkan kemampuan motorik kasar Anak usia dini meningkat dengan selisih 33,20\%.

\section{Pembahasan}

Pada dasarnya manusia lahir dengan kodratnya memiliki rasa ingin tau (curiosity) atas realitas yang ada. Hal ini disebabkan karena manusia memiliki cipta (kebenaran), rasa (keindahan) dan karsa (kebaikan) yang mendorong manusia berpikir dan berpengetahuan. ${ }^{6}$ Berdasarkan hasil analisis penelitian kemampuan motorik kasar anak usia dini melalui gerak dan lagu "Bernyanyi dengan Riang".

Hasil penelitian diatas dapat dilihat bahwa setiap penelitian yang telah dilakukan memperoleh hasil presentase yang menunjukan adanya peningkatan motorik kasar siswa walaupun berbeda-beda hasil peningkatannya, artinya bahwa dengan gerak dan lagu "Bernyanyi dengan

\footnotetext{
${ }^{6}$ Endang Fatmawati, Mata Baru Penelitian Perpustakaan, Yogyakarta: 2013. Hal 14
} 
Riang” dapat meningkatkan kemampuan motorik kasar anak usia dini. Karena dengan gerak dan lagu peserta didik merasa senang dan bahagia serta dapat mengingat pesan moral, pesan agama, dan gerakangerakan yang diajarkan

Dengan nilai rata-rata keseluruhan dari literatur yang dijadikan bahan penelitian dengan skor siklus I 54,28\% meningkat menjadi $87,48 \%$ dengan selisih rata-rata menjadi $33,20 \%$. Jadi, dari hasil penelitian literatur skripsi dan jurnal dengan pendekatan pembelajaran penggunaan metode gerak dan lagu untuk meningkatkan kemampuan motorik kasar Anak usia dini meningkat dengan selisih $33,20 \%$.

Merencanakan

pembelajaran harus dipersiapkan dengan matang. Guru harus memiliki pengetahuan situasi umum yang akan dihadapi, misalnya saja, tempat, situasi, dan lain-lain. Persiapan terhadap muridmurid dalam mempersiapkan pembelajaran guru juga harus mempersiapkan murid-murid, dan guru harus memiliki gambaran muridmuridnya. ${ }^{7}$

Cara yang paling tepat untuk mengembangkan kemampuan anak PAUD adalah melalui pembelajaran yang menekankan pada kegiatan bermain karena dunia anak adalah dunia bermain. Permainan yang digunakan di PAUD merupakan permainan yang didesain sedemikian rupa sehingga merangsang kreativitas anak dan menyenangkan, salah satunya dengan bernyanyi dengan riang. ${ }^{8}$

\footnotetext{
7 Mursid. (2018). Belajar dan Pembelajaran PAUD. Bandung : Remaja Rosdakarya. Hal 64

8 Mursid. (2018). Belajar dan Pembelajaran PAUD. Bandung : Remaja Rosdakarya. Hal 61.
}

\section{Penutup}

\section{Simpulan}

Berdasarkan hasil penelitian diatas tentang pembelajaran dengan meningkatkan kemampaun motorik kasar anak anak usia dini melalui gerak dan lagu "bernyanyi dengan riang". Hasil penelitiannya adalah bahwa setiap penelitian yang telah dilakukan dan telah memperoleh hasil persentase yang menunjukan adanya peningkatan motorik kasar anak, dapat disimpulkan bahwa:

Penelitian yang dilakukan oleh Luluk Muthoharoh. Penelitian ini menggunakan metode penelitian tindakan kelas dengan jumlah sebanyak 20 siswa, pada siklus I menunjukkan data $35 \%$ dan siklus II $85 \%$ menunjukkan peningkatan sebesar $50 \%$. Judul Penelitian yang dilakukan oleh Esa Muslimah. Penelitian ini menggunakan metode penelitian tindakan kelas dengan jumlah sebanyak 10 siswa, menunjukkan hasil pada siklus I sebesar $60,16 \%$ dan pada siklus II menjadi $83 \%$ menunjukkan peningktan yaitu sebesar 22,84\%. Penelitian yang dilakukan oleh

Fitri Triyana. Penelitian ini menggunakan metode penelitian tindakan kelas dengan jumlah sebanyak 20 siswa, pada siklus I menunjukkan 50 $\%$ dan pada siklus II dapat meningkatkan penguasaan gerak motorik kasar dengan baik yakni mencapai $94 \%$. Jadi peningkatannya mencapai $44 \%$. Penelitian yang dilakukan oleh Dwi Ginta Atik Khasanah. Penelitian ini menggunakan metode penelitian tindakan kelas dengan jumlah sebanyak 15 siswa, menunjukkan pada siklus I mencapai 
66,60\% dan siklus II mencapai 85,90\% peningkatannnya mencapai 19,3\%.

Penelitian yang dilakukan oleh Rikha Kusmalia dan Hanita. Penelitian ini menggunakan metode penelitian tindakan kelas dengan jumlah sebanyak 20 siswa, menujukkan data pada siklus I 53,7\% sedangkan pada siklus II menjadi $97,9 \%$ dan peningkatannnya mencapai $44,2 \%$.

Penelitian yang dilakukan oleh A.A Istri Intan Ari, I Ketut Gading, Putu Aditya Antara. Penelitian ini menggunakan metode penelitian tindakan kelas dengan jumlah sebanyak 15 siswa, menunjukkan pada siklus I sebesar 53\% yang berada pada kategori rendah dan terjadi peningkatan pada siklus II menjadi $82 \%$ dan berada pada kategori tinggi. Terjadi peningkatan yang signifikan sebesar $29 \%$.

Penelitian yang dilakukan oleh Sri Hartin Yuliana Dewi. Penelitian ini menggunakan metode penelitian tindakan kelas dengan jumlah sebanyak 13 siswa, menunjukkan Keterampilan motorik pada siklus I $61,52 \%$ dan pada siklus II mencapai $84,6 \%$ mengalami peningkatan sebesar $23,08 \%$.

Dengan nilai rata-rata keseluruhan dari literatur yang dijadikan bahan penelitian dengan skor siklus I 54,28\% meningkat menjadi $87,48 \%$ dengan selisih rata-rata menjadi $33,20 \%$. Jadi, dari hasil penelitian literatur skripsi dan jurnal dengan pendekatan pembelajaran penggunaan metode gerak dan lagu untuk meningkatkan kemampuan motorik kasar Anak usia dini meningkat dengan selisih 33,20\%.

Dari hasil penelitian yang dilakukan peneliti-peneliti sebelumnya baik skripsi dan jurnal bahwa dengan menggunakan gerak dan lagu "bernyanyi dengan riang" dapat meningkatkan motorik kasar pada anak usia dini, artinya terdapat peningkatan motorik kasar pada anak usia dini dengan menggunakan gerak dan lagu "bernyanyi dengan riang". Karena dengan gerak dan lagu peserta didik merasa senang dan bahagia serta dapat mengingat pesan moral, pesan agama, dan gerakan-gerakan yang diajarkan.

\section{Saran}

Berdasarkan hasil penelitian dengan Pembelajaran dengan menggunakan gerak dan lagu "bernyanyi dengan riang" untuk meingkatkan motorik kasar pada Anak Usia dini diatas, maka peneliti mengajukan beberapa saran diantaranya:

Bagi guru, disarankan agar menggunakan media pembelajaran dengan meggunakan gerak dan lagu "bernyanyi dengan riang" untuk meningkatkan motorik kasar pada anak usia dini dan meningkatkan kompetensi serta membekali diri dengan pengetahuan luas, karena sesungguhnya kompetensi guru sangat mempengaruhi keberhasilan proses belajar mengajar yang pada akhirnya akan menghasilkan anak yang berprestasi, berakhlakul karimah, dan berbudi pekerti luhur. Sehingga berdampak positif pada perkembangan dan kemajuan sekolah.

Bagi pihak sekolah, disarankan untuk lebih memperhatikan fasilitas dan melakkan koordinasi antar lembaga di lingkungan sekolah karena sangat menunjang bagi perkembangan anak.

Bagi Peneliti selanjutnya yang ingin mengadakan penelitian lebih lanjut tentang gerak dan lagu "bernyanyi dengan riang" untuk meningkatkan motorik kasar pada 
anak usia dini disarankan untuk lebih mendalami lagi, karena masih banyak hal menarik yang dapat diperoleh dengan menggunakan media pembelajaran ini.

\section{Daftar Pustaka}

Adi Walujo, Djoko dan Anies Listyowati. (2017). Kompendium PAUD : Memahami PAUD Secara Singkat. Jakarta : Prenada Media Kencana Group.

Dwi Astuti, Yuliani. (2018). Ayah, Ibu... Ajari Aku Lagu Sederhana. Suka Bumi : CV Jejak.

Fahmi. (2015). Permasalahan Anak Usia Dini : Mengenalkan Membaca permulaan Kepada Anak Usia Dini TK/RA dan SD Kelas Rendah. Serang : Untirta Press.

Fauziddin, Mohammad. (2015). Pembelajaran PAUD : Bermain, Cerita dan Menyanyi Secara Islami. Bandung : Remaja Rosda Karya.

Khadijah. (2016). Pengembangan Kognitif Anak Usia Dini. Medan : Perdana Publishing.

Latif, Mukhtar dkk. 2013. Orientasi Baru Pendidikan Anak Usia Dini : Teori dan Aplikasi. Jakarta : Kencana..

Masganti, Sit. (2015). Psikologi Perkembangan Anak Usia Dini Jilid I. Medan : Perdana Publishing
Masnipal. (2013). Siap Menjadi Guru dan Pengelola PAUD Profesional : Pijakkan Mahasiswa, Guru dan Pengelola TK/RA/KB/TPA. Jakarta : Gramedia.

Munafiah,Nida'ul dkk. (2018). Strategi Pembelajran Anak Usia Dini : Berbasis Multiple Intelegences. Wonosobo : Penerbit Mangku Bumi.

Mursid. (2015). Belajar dan Pembelajaran PAUD. Bandung : Remaja Rosdakarya.

Mursid. (2018). Belajar dan Pembelajaran PAUD. Bandung : Remaja Rosdakarya. Hal 64

Mursid. (2018). Belajar dan Pembelajaran PAUD. Bandung : Remaja Rosdakarya. Hal 61.

Mursid. (2015). Belajar dan Pembelajaran Paud. Bandung : PT Remaja Rosdakarya. Hal 12.

Mursid. (2015). Belajar dan Pembelajaran Paud. Bandung : PT Remaja Rosdakarya. Hal 38.

Mursid. (2015). Belajar dan Pembelajaran Paud. Bandung : PT Remaja Rosdakarya. Hal 107.

Mushlih, Ahmad dkk. (2018). Analisis Kebijakan PAUD : Mengungkap Isu-Isu Menari Seputar PAUD. Jawa Tengah : Penerbit Mangku Bumi.

Mutiah, Diana. (2010). Psikologi Bermain Anak Usia Dini. Jakarta: Kencana Prenada Media Group. 
Novi Mulyani. (2017). Pengembangan Seni Anak Usia Dini. Bandung : PT Remaja Rosdakarya.

Rahyubi, Heri. (2012). Teori-Teori Belajar dan Aplikasi Pembelajaran Motorik. Bandung : Nusa Media.

Rakhma, Eugenia. (2017). Menumbuhkan Kemandirian Anak. Yogyakarta : Stiletto Books.

Riva, Iva. 2012. Koleksi Games Edukatif Di dalam dan Luar Sekolah. Yogyakarta: Flash Books

Siregar, Alfitriani. (2018). Metode Pengajaran Bahasa Inggris Anak Usia Dini. Medan : Lembaga Penelitian dan Penulisan Ilmiah AQLI

Sudirjo, Encep dan Muhamad Nur Alif. (2018). Pertumbuhan dan Perkembangan Motorik : Konsep Perkembangan dan Pertumbuhan Fisik dan Gerak Manusia. Sumedang : UPI Press.

Sujiono, Yuliani. (2012). Konsep Dasar Pendidikan Anak Usia DIni. Jakarta : PT Indeks.

Sujiono, Bambang. (2017). Metode Pengembangan Fisik. Tangerang Selatan : Universitas Terbuka. Hal 1.5

Suyadi. (2015). Teori Pembelajaran Anak Usia Dini Dalam Kajian Neurosains. Bandung : PT Remaja Rosdakarya. Hal 102.
Suryana, Dadan. (2016). Stimulasi dan Aspek Perkembangan Anak. Jakarta : Kencana.

Susanto, Ahmad. (2014). Perkembangan Anak Usia DiniPengantar dalam Berbagai Aspeknya. Jakarta: Kencana Prenadamedia Group.

Susanto, Ahmad. (2015). Bimbingan dan Konseling di Taman KanakKanak. Jakarta : Prenadamedia Group.

Susanto, Ahmad. (2017). Pendidikan Anak Usia Dini : Konsep dan Teori. Jakarta : Bumi Aksara

Suyadi. (2015). Teori Pembelajaran Anak Usia Dini dalam Kajian Neurosains. Bandung: PT. Remaja Rosdakarya.

Umar Fakhruddin, Asef. (2010). Sukses Menjadi Guru TK-PAUD, Yogyakarta:Bening.

Yus, Anita. (2015). Penilaian Perkembangan Belajar Anak Taman Kanak-Kanak. Jakarta : Prenada Media Kencana group.

A.A Istri Intan Ari Lastari, Ketut Gading, Putu Aditya Antara. eJournal Pendidikan Anak Usia Dini Universitas Pendidikan Ganesha. Jurusan Pendidikan Guru Pendidikan Anak Usia Dini (Volume 4. No. 2 Tahun 2016). Penerapan Pembelajaran Gerak dan Lagu Berbantuan Audiovisual untuk Meningkatkan Kecerdasan Kinestetik pada Anak Kelompok $B$. Universitas Pendidikan Ganesha Singaraja Indonesia. 
Ginta Atik Khasanah, Dwi. (2018). Jurnal: Meningkatkan Kemampuan Motorik Kasar Anak Melalui Kegiatan Gerak dan Lagu TK B di TK Pertiwi Kedungupit. Program Studi Pendidikan Guru Pendidikan Anak Usia Dini. Fakultas Keguruan dan Ilmu Pendidikan Universitas Muhammadiyah Serakarta.

Hartin, Sri, Yuliana Dewi. (2015). Jurnal: Meningkatkan Keterampilan Motorik Kasar Anak Melalui Kegiatan Gerak dan Lagu di Kelompok A TK ABA Lambara Tawaeli. Program Studi PG PAUD. Jurusan Ilmu Pendidikan. Fakultas Keguruan dan Ilmu Pendidikan. Universitas Tadulako. No. Stambuk: A451 11 097.

Kintani Ishud, Nurul dan Nurfaizah Romadona. (2020). The $2_{n d}$ Internasional Conference on Elementary Education Volume 2 Nomor 1, ISBN 978-623-7776-079. A Review of The Effect of Nutrition Status on Gross Motor Skills of Early Childhood. Early Childhood Education Department. Universitas Pendidikan Indonesia, Bandung

Kusmalia, Rika Dan Hanita. Jurnal Warna : Jurnal Pendidikan Dan Pembelajaran Anak Usia Dini. September 2017. Vol 02. No 02. Meningkatkan Kemampuan Motorik Kasar Anak Melalui Gerak dan Lagu Usia 5-6 Tahun di TK PGRI Marangkayu Tahun Ajaran 2017/2018.
Muslimah, Esa. (2019). Skripsi : Peningkatan Kemampuan Motorik Kasar Anak Usia 5-6 Tahun Melalui Permainan Lompat Tali Di Paud Al-Ikhlas Tangerang Selatan. Jurusan Pendidikan Islam Anak Usia Dini. Fakultas Ilmu Tarbiyah Dan Keguruan Universitas Islam Negeri Syarif Hidayatullah Jakarta.

Muthoharoh, Luluk. (2019). Skripsi: Upaya Meningkatkan Motorik Kasar Melalui Gerak dan Lagu Pada Kelompok B TK Madinah Azzahro Bandar Mataram Lampung Tengah. Jurusan Pendidikan Islam Anak Usia Dini (PIAUD). Fakultas Tarbiyah dan Ilmu Keguruan. Institut Agama Islam Negeri Metro.

Rifatin. (2019). As-Sabiqun: Jurnal Pendidikan Islam Anak Usia Dini Volume 1, Nomor 1 Maret 2019; 68-79. Optimalisasi Metode Gerak serta Lagu untuk Meningkatkan Kecerdasan Peserta Didik. Universitas Nurul Jadid. Paiton Probalinggo Jawa Timur.

Tri Kurniati Sudjono, Elisabeth. Eny Kusumastuti. (2017). Jurnal Seni Tari JST 6 (2): Proses Pembelajaran Gerak dan Lagu yang Kreatif Berdasarkan Kurikulum 2013 di TK Miryam Semarang. Jurusan Sendratasik, Fakultas Bahasa dan Seni, Universitas Negeri Semarang. http://journal.unnes.ac.id/sju/inde x.php/jst 
Triyana, Fitri. (2017). Skripsi: Peningkatan Kemampuan Fisik Motorik Kasar Melalui Metode Gerak Dan Lagu Pada Anak Usia Dini Di Ra Rowosari Kecamatan Tuntang Kabupaten Semarang
Tahun Pelajaran 2016/2017. Jurusan Pendidikan Islam Anak Usia Dini. Fakultas Tarbiyah Dan Ilmu Keguruan. Institut Agama Islam Negeri Semarang. 